\title{
Washington Consensus Reforms and Economic Performance in Sub-Saharan Africa: Lessons From the Past Four Decades*
}

\author{
Belinda Archibong ${ }^{\dagger}$ \\ Barnard College
}

\author{
Brahima Coulibaly ${ }^{\ddagger}$ \\ Brookings Institution
}

\author{
Ngozi Okonjo-Iweala ${ }^{\S}$ \\ Brookings Institution
}

December 3, 2020

\begin{abstract}
Over three decades after market-oriented structural reforms, termed "Washington consensus" policies, were first implemented, we revisit the evidence on policy adoption and the effects of these policies on socio-economic performance in sub-Saharan African countries. We focus on three key ubiquitous reform policies around privatization, fiscal discipline, and trade openness and document significant improvements in economic performance for reformers over the past two decades. Following initial declines in per capita economic growth over the 1980s and 1990s, reform adopters experienced notable increases in per capita real GDP growth in the post 2000 period. We complement aggregate analysis with four country case studies that highlight important lessons for effective reform. Notably, the ability to implement pro-poor policies alongside market oriented reforms played a central role in successful policy performance.
\end{abstract}

JEL classification: O10, O43, N37

Keywords: Washington Consensus, Structural Adjustment Programs, Policy Reform, Africa

${ }^{*}$ Ngozi Okonjo-Iweala is Nonresident Distinguished Fellow with the Global Economy and Development program at Brookings, Chair of the Board of the Global Alliance for Vaccines and Immunization, and former Finance Minister of Nigeria; Brahima Coulibaly is Vice President of the Global Economy and Development at Brookings; and Belinda Archibong is Assistant Professor of Economics at Barnard College, Columbia University. The authors gratefully acknowledge helpful input from Peter Henry and comments from Anusha Chari as well as outstanding research support from Christopher Heitzig and Gloria Kebirungi. All errors are the authors' own.

†Barnard College, Columbia University. 3009 Broadway, New York, NY 10027, USA. ba2207@columbia.edu.

${ }_{\ddagger}^{\ddagger}$ Brookings Institution. BCoulibaly@brookings.edu.

${ }^{\S}$ Brookings Institution. 


\section{Introduction}

When economist John Williamson coined the term "Washington Consensus" in 1989, he was referring to a set of ten market-oriented policies that were popular among Washington-based policy institutions, particularly as policy prescriptions for improving economic performance in Latin-American countries (Williamson, 1993). These policies centered around fiscal discipline, market-oriented domestic reforms, and openness to trade and investment. In African countries, the Washington Consensus inspired market-based reforms prescribed by international financial institutions (IFIs) like the World Bank and the International Monetary Fund (IMF), under "structural adjustment programs" (SAP). These reforms were often prerequisites for financial assistance to indebted African countries during the global recession and debt crisis of the 1980s, when the external debt rose sharply to unsustainable levels (Onyekwena and Ekeruche, 2019; Naiman and Watkins, 1999; Mkandawire and Soludo, 1999).

The story of how African countries got into a debt crisis that led to the introduction of structural adjustment programs is often told as follows: first, expansionary fiscal spending aimed at economic development spearheaded by newly independent African governments, struggling to recover from the ravages of European colonialism, increased government spending in the 1960s and 1970s. Governments also borrowed significantly to finance development expenditures over this time. Oil price shocks that significantly decreased the price of oil in 1980s led to declines in export revenue for many governments. This decline in export revenue, along with a collapse in world prices of primary agricultural commodities, which made up 88 percent of Africa's exports, resulted in a shortfall in revenue that put enormous pressure on governments' finances (Onyekwena and Ekeruche, 2019; Mkandawire and Soludo, 1999). Additionally, government featured largely in domestic financial institutions like the banking sector, with many African governments nationalizing foreign banks or creating new state-owned financial institutions (Mkandawire, 1999). 
The global recession in the early 1980s, along with an increase in interest rates in donor countries, also raised interest payments on previously contracted loans, markedly increasing the debt burden of African countries and leading to the debt crisis of the 1980s (Onyekwena and Ekeruche, 2019; Due and Gladwin, 1991). By the early 1980s, African governments were in severe financial straits and, with lowered incomes, increasing poverty, and declining welfare, turned to IFIs for debt relief. Among the conditions for relief, countries had to first agree to economic and financial reform policies along the lines of those outlined in the Washington Consensus to achieve macroeconomic stability and efficiency. The expectation was that market-oriented reforms would correct domestic policy-induced distortions in prices, such as overvalued exchange rates, subsidies that led to artificially low agricultural commodity prices, high wage rates, low interest rates and subsidized input prices, which introduced inefficiencies in resource allocation, with detrimental effects on the economy in the long-run (Due and Gladwin, 1991; Williamson, 1993; Easterly, 2019; Chari, Henry, and Reyes, 2020).

The underlying assumption, as other scholars have pointed out, was that competitive markets would work well to efficiently allocate resources to residents in these African countries suffering under the burden of debt and illiberal fiscal and monetary policies (Easterly, 2019). Hence, market-based policies like privatizing public enterprises, removing or relaxing exchange rate controls that biased export trade towards certain commodities and fiscal adjustment to balance budgets by reducing spending on subsidies would support stronger economic growth. Several African countries adopted these market-oriented policies beginning in the 1980s. The number of reform adopters increased further following the introduction of the Highly Indebted Poor Countries (HIPC) initiative by the World Bank and IMF in the mid-1990s. The HIPC program provided debt relief to countries with 'unsustainable' debt provided they enacted many of the SAP policies (Onyekwena and Ekeruche, 2019). It has been over three decades since these policies were first adopted across Africa and other 
developing countries, yet the evidence of their impact on economic outcomes has not been conclusively established in the literature.

Most early literature finds that the policies failed to improve economic conditions in African countries for several reasons centered on the failure to account for political economy within countries, and the politics of conditionality and reforms that did not adequately emphasize the role of local ownership in shaping domestic economic policy(Ekpo, 1992; Easterly, 2000; Due and Gladwin, 1991; Birdsall, Caicedo, and De la Torre, 2010; Adedeji, 1999; Mkandawire and Olukoshi, 1995; Rodrik, 2006; Stiglitz, 2005). Other studies attribute the failures of the reforms to increases in domestic inflation and its adverse effect on real incomes and well being post-reform (Due and Gladwin, 1991; Ekpo, 1992). The negative effects of the reforms were also disproportionately felt by rural farmers, especially women working in food crop production. Ironically, while IFIs were advocating for the removal of agricultural subsidies in Africa, the advanced economies, including the United States and OECD countries, heavily subsidized agricultural production making it difficult for African farmers to compete (Due and Gladwin, 1991; Mkandawire and Olukoshi, 1995). The outcome of these market-oriented reforms was increased unemployment and socio-political unrest in several African countries in the 1980s and 1990s (Mkandawire and Olukoshi, 1995; Due and Gladwin, 1991; Ihonvbere, 1993; Elson, 1995).

A more recent literature has highlighted that the reforms were successful in improving economic growth, particularly when policymakers had the state capacity to implement them (Prati, Onorato, and Papageorgiou, 2013; Grier and Grier, 2020; Dollar and Svensson, 2000). Taken at face value, these studies suggest that the de facto reductions in state capacity required by some reforms may have contributed to their failure in some countries. For instance, the ratio of civil servants to the population in all sub-Sahara Africa (SSA) fell to 1 percent in 1996, lower than the 3 percent for other developing countries and much lower than 
the OECD average of 7 percent (Sender, 1999). Without a motivated, well-equipped, civil service, proper implementation and regulation of these reforms was often incredibly difficult.

Over 30 years after the initial adoption of reforms in African countries, we re-examine the relationship between reform adoption and economic performance. The predictions of the Washington Consensus policies amount to the following testable hypotheses: (i) First, countries that implemented the market-oriented reforms will experience better economic outcomes in the following years compared to the years preceding the reforms; and (ii) second, countries that implemented reforms will perform better than the countries that did not. Since the early 2000s, African economies have experienced remarkable improvement in economic growth, with median country real GDP per capita growth rising from 0.2 percent per year on average in the 1980s and 1990s, when many of the reforms were first implemented, to 1.6 percent over 2000 to 2019 as shown in Figure 1. The reforms also aimed to achieve lower and more stable inflation rates, partly through improved fiscal discipline. The rate of inflation in the region declined from double digits in the 1980s and 1990s to stabilize at around 5 percent in the past two decades (Figure 2), suggesting that inflation stabilization has been relatively successful in many African countries. These observations raise the question of whether the reforms of the 1980s and 1990s could have played a role in the region's improved economic performance of the past two decades.

With the benefit of more recent data, we revisit whether market-oriented reforms of the 1980s and 1990s may have contributed to the positive economic outcomes for sub-Saharan Africa over the past decades, considering plausible alternative explanations. We refer to the economic literature on key Washington consensus policy reforms and classify them into three broad categories namely: (i) Reforms aimed at achieving fiscal discipline (fiscal reforms); (ii) reforms aimed at reducing the role of government in the local economy (domestic marketoriented reforms), and (iii) reforms aimed at achieving greater economic openness to trade 
and investment (openness reforms).

Our results indicate that during the initial reform years, economic performance was worse for reform adopters, with average per capita real GDP growth declining in the 1980s and 1990s. In contrast, non-reform adopters experienced positive growth over this period, consistent with the earlier literature showing that the reforms failed to bring about short-run economic growth. Between 2000 and 2019, average per capita GDP growth was higher than during the 1980s and 1990s for both reformers and non-reformers. However, the increase in growth was even higher for reform adopters. When we examine these comparative statistics by reform category, the difference in performance between reformers and non-reforms is largely driven by adoption of fiscal and domestic market-oriented reforms.

We explore the role of alternative explanations, specifically, the increase in commodity prices and the effect of debt relief on economic performance for several countries in the 2000s. We find that the post-2000 per capita GDP growth was higher for non-commodity dependent countries compared with commodity dependent countries. Additionally, among the commodity-dependent countries, the per capita GDP growth was higher for reformers compared with non-reformers. For debt relief, countries that benefited from debt forgiveness experienced higher per capita GDP growth compared with countries that did not. Among the countries that benefited from debt relief, reformers generally experienced a higher per capita GDP growth. While it is difficult to draw definitive conclusions from the simple analyses in this study, the result point to a reversal of the economic fortunes of reform adopters in the last two decades following their initial dismal economic performance during the 1980s and 1990s.

To enrich the aggregate analysis, we conduct four case studies for Ethiopia, Nigeria, Uganda, and Senegal, which allow for a more granular and nuanced assessment of the effect of the reforms. Overall, the case studies support the aggregate findings and reveal some 
useful lessons on the correlates of successful reform implementation. A stable government and socio-political environment with a focus on pro-poor policies was an essential ingredient in implementing successful reforms. Crucially, concurrent efforts to minimize the potential negative welfare impacts of macroeconomic reforms on domestic populations are important to increase needed public support for reforms.

The rest of the paper is organized as follows. Section 2 provides a detailed review of Washington Consensus reform policies. Section 3 presents a comprehensive assessment of the reforms including their adoption trends across sub-Saharan Africa, and conducts a comparative analysis of the economic growth patterns between reform adopters and nonadopters. Section 4 explores alternative explanations for the improved growth performance of the past two decades. Section 5 examines the reform experiences of four different countries. Section 6 concludes.

\section{Washington Consensus Policies and Structural Adjustment Pro- grams}

A first step to understand the economic effects of Washington Consensus policy adoption is to examine the proposed reforms and the drivers of policy adoption across African countries. Washington Consensus reforms, as outlined in Serra and Stiglitz (2008), included the following 10 policy recommendations:

- "Fiscal discipline" focused on ensuring countries had relatively low primary fiscal deficits to avoid balance of payment crises and high inflation;

- "Reordering public expenditure priorities" encouraged elimination of subsidies and increased expenditure on pro-poor programs, including health care, education and infrastructure; 
- "Tax reforms" emphasized the need for a broad-based tax base with moderate marginal tax rates;

- "Interest rate liberalization" aimed at promoting market-determined interest rates and achieving positive real interest rates;

- "Competitive exchange rates" to correct overvalued exchange rates;

- "Trade liberalization" to allow more openness to trade with varying views on the pace at which to proceed;

- "Liberalization of Inward Foreign Direct Investment" to attract foreign capital but not including capital account liberalization;

- "Privatization" highlighted the potential benefits of privatizing state-owned enterprises by either selling assets into a competitive market or regulating them properly;

- "Deregulation" aimed at easing barriers to entry and exit, but not abolishing regulations designed for safety or environmental reasons or to govern prices in a noncompetitive industry;

- "Legal security for property rights" to facilitate the acquisition of property rights, notably in the informal sector.

For the purpose of this study, we classify the Washington Consensus policies in three main categories: Fiscal policy reforms (fiscal discipline, reordering of public expenditure priorities, tax reforms); domestic market-oriented reforms (interest rate liberalization, privatization, deregulation, legal security for property rights), and openness reforms (liberalization of inward FDI, trade liberalization, competitive exchange rates). To differentiate between reformers and non-reformers, we adopt the following rules: A country is a fiscal reformer if the average primary fiscal balance in 1995 to 1999 is higher than -0.7, which is the median for the 
region; a country is a domestic market reformer if the cumulative number of privatizations deals from 1988 to 1999 is greater than or equal to 6, which is the median for the region; a country is an openness reformer if it was open to trade, as defined in Sachs and Warner (1995), for at least five years from 1980 to 1999. There is, admittedly, some subjectivity in these rules. In practice, because the approach to reforms is not binary, by construction, the classification mostly distinguishes between those who enacted the most reforms and those who reformed the least.

Table 1 shows the classification of countries by reform categories. Of the 32 subSaharan African countries for which we have data, 59 percent are fiscal reformers. Of the 36 countries for which we have data, 42 percent are domestic market reformers and 47 percent are openness reformers. Six countries (Benin, Cote d'Ivoire, Kenya, Mozambique, Tanzania, and Uganda) are reformers in all three categories.

\section{Reform Adoption and Economic Performance}

The premise of the Washington Consensus policies reforms rested on two interdependent and testable hypotheses: first, in the years following the reforms, economies that adopted reforms would perform better than they did in the preceding years and, second, reform adopters would outperform non-reformers. In the following sections, we examine the links between reform adoption and the region's economic performance, as measured by per capita GDP growth.

\subsection{Fiscal Policy Reforms}

Figure 3 shows the evolution of the primary fiscal balance in the region. The median deficit declined from -2 percent in the early 1980s to -0.7 in the late 1990s, suggesting an increase in fiscal discipline across the region. The reduction in the deficit continued through 2010 
but widened afterwards due partly to the effects of the Global Financial Crisis of 200809 and the 2014 terms of trade shock.

Table 2 summarizes the results showing the trends in per capita GDP growth rates for reformers and non-reformers for all countries and by reform category. Overall, the median GDP per capita growth was slightly positive (0.2 percent) across the region between 1980 and 1999. Between 2000-2019, the growth rate rose by 1.4 percentage points to 1.6 percent. However, performance varied by reform categories. Fiscal reformers in the 19801999 period experienced negative growth rates, with the trends reversing sharply in the post-2000s era. Comparing the two sets of countries, per capita GDP growth rate was slightly higher for non-reformers than for reformers over the past two decades. However, the per capita GDP growth rate increased by more for reformers compared with non-reformers between 1980-1999 and 2000-2019, consistent with, but not conclusive confirmation of, the positive long-run predictions of reform adoption for economic performance.

\subsection{Market-Oriented Reforms and Economic Performance}

No comprehensive and reliable measures were available for deregulation, legal security for property rights and interest rate liberalization. Given the paucity of data and previous literature highlighting privatization as a key policy under Washington Consensus reforms, we use privatization as a proxy for domestic market-oriented reforms (Parker and Kirkpatrick, 2005). The share of countries with one least one privatization deal rose from 5 percent in 1988 to reach 40 percent in the late 1990s as shown in Figure 4. Similarly, the number of enterprises privatized increased significantly from just three in 1988 to 160 in 1996 as shown

in Figure 5. This acceleration in the pace of privatization was consistent with the push to privatize several state-owned enterprises (SOEs) as a strategy to consolidate fiscal balances in some cases. 
Previous scholars have highlighted the serious challenges faced by African countries in the planning and implementation of privatization policies under conditionality and in environments of incomplete markets and weak enforcement capacity (Bayliss and Cramer, 2003; Ariyo and Jerome, 1999). Although the Washington Consensus framework recognized the importance of complete markets and proper regulation as preconditions for successful privatization, these caveats were often overlooked in policy design at IFIs. Many IFIs failed to adequately highlight the importance of anti-trust legislation in promoting competitive markets along with privatization reforms. They also underestimated the effects of rapid privatization on the morale of public sector employees, who were essential for proper regulation of the process (Bayliss and Cramer, 2003; Ariyo and Jerome, 1999). Many of these issues may have contributed to the poor economic performance for reformers between 1980 and 1999.

The pace of privatization varied across the region. While some countries, including Cote d'Ivoire, Uganda, Nigeria, Ghana, Kenya, Mozambique, Zambia and Tanzania, privatized more than 50 SOEs between 1988 and 1999, others, including Gabon, Mauritius, Rwanda, Equatorial Guinea, Gabon, and Central African Republic, did not privatize any SOEs over this period. Table 2 shows the average performance between reformers and non-reformers. Similar to the results of the fiscal reforms, market reformers experienced declines in per capita GDP growth over the reform period from 1980-1999, followed by a sharp reversal post 2000. Over 2000-2019, growth rates for reformers and non-reformers looked very similar at 1.5 percent and 1.6 percent on average, respectively. However, the set of countries that privatized the most in the late 1980s and in the 1990s, experienced a much higher increase in average real GDP per capita growth in the last two decades: 2.1 percentage points compared with 1.4 percentage points for the non-reformers. 


\subsection{Openness and Economic Performance}

Openness to trade and investment, notably Foreign Direct Investment (FDI), are key policy recommendations under the Washington Consensus framework. To assess Africa's experience with trade liberalization, we define trade openness following Sachs and Warner $(1995)^{1}$. Figure 6 indicates that sub-Saharan Africa increasingly opened to trade in the 1980s and 1990s. In the early 1980s, only 5 percent of the countries were classified as open to trade. That share rose to reach almost 60 percent by 2000. Around the same period, African countries accelerated the adoption of more competitive exchange rates. This was reflected in the increase in the share of countries with floating or semi-floating exchange rates from 45 percent in 1980 to 60 percent in the early 1990s. While trade-openness increased, previous scholars have highlighted that this did not translate to immediate increases in investment in sub-Saharan Africa as shown in Figure 7 (Sender, 1999). Cuts in public investment to adhere to fiscal reforms contributed to the decline in investment (Sender, 1999).

In addition, many trade liberalization policy reforms undertaken over this period underestimated the role of incentives facing producers in incomplete markets. Liberalization in the agricultural sector, hastily implemented, negatively impacted terms of trade for farmers who were sometimes unable to compete with international prices (Sender, 1999). Higher prices for agricultural commodities in the 1980s and 1990s worsened food shortages and led to protests in African countries (Herbst, 1990). These events, in concert, may have also contributed to the steep reductions in aggregate investment in the 1980s.

Despite initial reductions in total investments across the continent in the early part of the reform years, countries that adopted trade openness reforms experienced small positive

\footnotetext{
${ }^{1}$ A country is classified as "open" to trade if does not have any of the following: 1) average tariff rates in excess 40 percent; 2) Non-tariff barriers cover more than 40 percent of imports; 3) It has a socialist economic system; 4) The state has a monopoly on major exports; 5) The black market currency-trading premium exceeds 20 percent.
} 
growth rates over 1980 to 1999. Real GDP growth per capita increased for both reformers and non-reformers between 1980-1999 and 2000-2019. The increase was roughly comparable for reformers and non-reformers, although reform countries ended up with higher growth rates of 1.9 percent in the 2000 to 2019 period.

\section{Discussion of Alternative Explanations for Post 2000s Economic Performance}

Our analysis compared the economic performance during the initial reform period to the post-2000 years, and between reformers and non-reformers, providing suggestive evidence of differential trends both for reform countries over time and across reform and non-reform countries as well. In this section, we assess plausible alternative, but not necessarily mutually exclusive, explanations for the region's improved economic performance over the past two decades. One such explanation is that African countries benefited from debt relief and the resulting additional fiscal space allowed governments to increase public expenditures to boost economic growth. A second alternative explanation is that African countries benefited from the sustained increase in commodity prices in the early 2000s, driven, in part, by the high demand from China, and known as the commodity super-cycle (Fernández, Schmitt-Grohé, and Uribe, 2020).

\subsection{Debt Forgiveness}

Beginning in the 1990s, officials from major creditor countries (a group known as the Paris Club) and multilateral organizations adopted the ambitious Multilateral Debt Relief Initiative (MDRI) for outright forgiveness of debt owed by a group of 36 low-income countries. Most of these countries, 29 of the 36, were African. The MDRI was the logical advancement of a variety of initiatives for debt relief, the most prominent of which was the Heavily In- 
debted Poor Countries (HIPC) initiative instituted by the IMF and World Bank in 1996 to address debt overhang in the poorest countries of the world. A snapshot of HIPC countries is shown in Figure 8. African countries had been borrowing into the 1980s, which led to an increasing accumulation of debt that became unsustainable following the recession over this period.

The debt relief initiatives, including MDRI, were expected to improve economic performance in countries. Unloading of the debt overhang, infusion of new loans, improved policies, along with enhanced investment incentives were expected to increase economic and social development outcomes. Some previous evidence has shown positive correlations between reduced debt burdens and economic upturns (Coulibaly, Gandhi, and Senbet, 2019). The average public debt level (as a percentage of GDP) for sub-Saharan Africa declined to about 36 percent in 2012, significantly below the levels leading up to the HIPC initiative. To explore the economic performance for countries that experienced debt forgiveness and Washington consensus policy reform adopters, we can compare the economic performance of countries that benefited from the debt relief to that of the countries that did not.

As shown in Table 3, countries that benefited from debt relief experienced higher increases in per capita economic growth over the last two decades, 2.3 percentage points, compared with 0.3 percentage points for the countries that did not receive debt relief. Countries that received debt relief had lower average growth rates between 1980 and 1999 than non-debt relief recipients, with growth rates similar between debt relief and non-debt relief countries at 2 percent over 2000-2019. Debt relief through programs like HIPC was often conditioned on strict adoption of market liberalization reforms like those outlined in Washington Consensus policies. Indeed, many of the reforms undertaken by African countries in the 1990s were often initiated with an objective to reach certain debt relief eligibility targets (Ekpo, 1992; Sender, 1999). Disentangling patterns and trends between reform adopters 
and the debt relief recipients is difficult to do with summary statistics. A simple analysis of patterns and trends over this period shows that, among the beneficiaries of debt relief, the countries that adopted fiscal and market-oriented reforms posted higher economic growth than non-adopters. There do not appear to be significant differences in growth rates between the 1980-1999 reform period and the post-2000s era for debt relief recipients that adopted more trade-openness reforms.

\subsection{The Commodity Super-Cycle}

In the 2000s, commodity prices surged in response to higher demand from emerging market economies, notably China, as well as from concerns over long-term supply. The commodity super cycle was disrupted during the 2008 to 2009 crisis and, subsequently, the late 2014 adverse terms of trade shock. Despite these shocks, higher commodity prices over much of the past two decades benefited several commodity dependent countries (Figure 8). As shown in Table 4, both commodity dependent and non-commodity dependent countries experienced higher GDP per capita growth between 2000 and 2019 compared to the previous two decades. In fact, the increase in per capita GDP growth rate was higher for non-commodity dependent countries, 1.9 percentage point compared with 1.4 percentage point for commodity dependent countries $^{2}$.

Finally, per capita GDP growth averaged 2 percent between 2000 and 2004 before the commodity prices began their rapid ascent (Coulibaly, 2017), suggesting that the increase in commodity prices was not the sole driver of the post 2000 economic performance. An examination of the trends in growth rates among commodity dependent countries between reformers and non-reformers shows that countries that adopted market reforms like privatization and trade openness posted higher increases in average growth rates between 1980 to

\footnotetext{
${ }^{2}$ We define commodity dependence according the International Monetary Fund (2016)'s definition of resource-intensive countries.
} 
1999 and 2000 to 2019. For fiscal reformers, in contrast, there appears to be no discernible difference in growth rates.

The results suggest that both the debt relief and commodity prices may have also contributed to the higher per capita economic growth of the last two decades. Within the beneficiaries of debt relief and commodity dependent, reformers generally posted larger growth gains between the reform period and the post-2000s era, suggesting that reforms may have played a role in improving economic performance, independently of the commodity price boom and debt relief.

\section{$5 \quad$ Washington Consensus and Select Country Experiences}

The analysis so far has taken a broad-brush approach to examining the links between Washington consensus policy adoption and economic performance in Africa. To complement and enrich the discussion on the regional experience, we explore the reform experience in four countries with very different implementation approaches: Ethiopia, Nigeria, Uganda, and Senegal.

\subsection{Ethiopia's Experience}

Following the account in Devarajan, Dollar, and Holmgren (2002), Ethiopia's reform experience was largely a story of poor outcomes. In the 1980s, the country was immersed in a civil war and struggled to implement reform during significant political and economic crises. It adopted a few financial liberalization and stabilization policies from 1990 to 1995, including infrastructure investment as well. It also engaged in several privatization deals around land, reformed the banking system and granted autonomy to the National Bank of Ethiopia, and attempted to create a more competitive private sector. With weak state capacity, promoting development and financial stabilization amidst a civil war made attempts at reform an 
arduous process in Ethiopia. The lack of significant adoption of reforms is captured in the classification provided in Table 1; Ethiopia does not feature among the reform countries on any of the three measures.

Nonetheless, Ethiopia has consistently ranked among the top economic performers in the region for much of the past decade and a half, with an average growth rate of real GDP of 8.9 percent between 2000 and 2019. Much of this growth has been attributed to public investment in key infrastructure along with interventions in the agricultural sector to improve productivity and facilitate structural transformation. There has also been a reallocation of labor from low productivity agriculture to more productive industrial and service sectors in the country.

\subsection{Nigeria's Experience}

Of the three key reforms described in Section 3, Nigeria scored highly on two: domestic market oriented reforms around privatization and fiscal reforms aimed at improving the fiscal balance over the 1980 to 1999 period as shown in Figure 3. Previous work has described the Nigerian economic experience post policy adoption in the 1980s as dismal by citing decreases in GDP growth rates from 6.9 percent pre-adjustment to -1.7 percent in the postperiod (Ekpo, 1992). In Nigeria, the main determinant of adoption of World Bank-funded reforms was the pressure to reach agreements on debt rescheduling (Ekpo, 1992; Devarajan, Dollar, and Holmgren, 2002).

The second main determinant was the nature of leadership in power at the time and its commitment to the reform process. Nigeria has been a heavily oil commodity dependent country since the 1970s, with over 70 percent of government revenue from petroleum and petroleum exports as a share of total exports growing to over 90 percent in the 2000s (Archibong, 2018). The heavy dependence on oil exports has made the country very vulnerable to 
external price shocks, with deleterious implications for the ability to finance public spending and debt (Okonjo-Iweala, 2014). Following a drop in oil prices to between $\$ 8$ and $\$ 10$ per barrel in 1985-1987, and subsequent steep increases in the country's debt to GDP ratio, Nigeria implemented policy reform in the form of structural adjustment programs with the support of the IMF and World Bank under then military president General Ibrahim Babangida.

A key driver of reform adoption was pressure to reach agreements on debt rescheduling as mentioned earlier. The reform focused on fiscal tightening and privatization but also induced severe cuts in social spending on education and health which reduced the wellbeing of Nigerian citizens and increased hostility for the reforms in the 1980s and 1990s, contrary to the Washington Consensus which emphasize reorientation of spending toward pro-poor programs. The reforms were subsequently abandoned by the Babangida regime and the country continued to be beset by poor macroeconomic policy over the following decades of military rule. As an illustration, Nigeria continued to borrow and accumulated up to $\$ 30$ billion in debt to the Paris Club of Creditors even though the country earned more than $\$ 300$ billion in crude oil revenues over the 1970s-2001 period (Okonjo-Iweala, 2014). The debt became incredibly difficult to service during periods of low oil prices in the mid-1980s. And while some of the oil revenue and borrowed money was invested in needed infrastructure, education and health, lack of monitoring of spending and opaque ad-hoc budgets meant there was a significant amount of spending on "white elephant" projects like unproductive steel mills.

Following the transition to democracy in 1999 and under the helm of then President Olusegun Obasanjo, Nigeria was faced with an unstable macroeconomic environment characterized by volatile exchange rates, double digit inflation (23 percent per year in 2003), a relatively high fiscal deficit (3.5 percent of GDP in 2003) and low GDP growth (2.3 percent on average for the previous decade). 
The country embarked on macroeconomic reforms under then finance minister Ngozi Okonjo-Iweala aimed at stabilizing the macroeconomic environment and improving social indicators and general economic performance. The focus of the reforms was on privatization, budget monitoring and, crucially, investment in education and health under the National Economic Empowerment and Development Strategy (NEEDS). As part of the NEEDS policy and to reduce volatility in public finances, Nigeria adopted an oil price-based fiscal rule (OPFT) that used the long-run (10 year) average oil price to set government budgets and targets for spending. Based on the rule, the government would set aside some excess revenues from oil in the form of a savings account called the Excess Crude Oil Account (ECA) headquartered at the central bank. The fiscal rule, which was institutionalized in national law in the Fiscal Responsibility Act signed in 2007, linked savings to fiscal discipline around government spending, aiming for a fiscal deficit of 3 percent of GDP. The policy was successful both in building fiscal discipline and helping Nigeria weather shocks like the financial crisis of 2008-2010 when oil prices fell from over $\$ 140$ to $\$ 40$ per barrel.

Over this period, Nigeria was able to draw on savings from the ECA to implement a fiscal stimulus of around 0.5 percent of GDP and maintain public spending. Increased public savings between 2004 and 2006 as a result of policy reform had real positive effects on macroeconomic performance- leading to fiscal surpluses of 7.7 percent of GDP in 2004 and 10 percent of GDP in 2005. The increased public spending enabled Nigeria to pay off its external debt arrears of about $\$ 6$ billion, increase its foreign reserves from $\$ 7$ billion in 2003 to $\$ 46$ billion by the end of 2006 , and implement tighter monetary policy to reduce inflation from 21.8 percent in 2003 to 10 percent in 2004. The $\$ 6$ billion in arrears was paid as part of debt relief of a $\$ 30$ billion debt, of which $\$ 18$ billion was completely written off by the Paris Club. This also helped to spur private sector investment. Growth averaged 8.1 percent a year from 2003 to 2006 and the share of spending on health and education rose to 5 percent and almost 10 percent, for health and education in 2007, respectively. 
Reforms also targeted sectors that were large drains on public finances for privatization in the telecommunications sector, the downstream petroleum sector and the power sector, to name a few, with varying degrees of success. Nigeria also benefited from the increase in oil prices in the post 2000 period, and both the reforms and increases in prices combined to create an attractive environment for private investors in the country.

\subsection{Uganda's Experience}

Uganda, unlike its Nigerian counterpart, is often touted by IFIs as an example of successful application of reforms, although the details of reform present a mixed picture (Devarajan, Dollar, and Holmgren, 2002). Of the three key reforms described in Section 3, Uganda was one of a handful of countries that scored highly on all three: domestic market-oriented reforms around privatization, fiscal reforms aimed at improving the fiscal balance and increased trade openness over the 1980 to 1999 period.

Between 1971 and 1986, Uganda experienced economic decline, but GDP per capita rose by almost 40 percent between 1986 and 1996. In 1987, the country attained an IMF loan, with loan renewals occurring from 1989-1992 and again from 1992 to 1997. Real GDP per capita grew on average 4.2 percent per year between 1992 and 1997. The two main reforms mandated by the IMF in Uganda were trade liberalization and the progressive reduction of export taxation. The benefits of liberalized cash crop exports were large but limited and unequally distributed, with only a small number of rural coffee farmers experiencing increases in rural per capita incomes over the period of policy reform from 1988 to 1995.

Uganda also privatized its public enterprises in a move that was highly criticized within the country. The main critique was that the privatization had proceeded too rapidly, with relatively little oversight. As a result, the privatizations benefited government and corporate interests of advanced economies rather than the Ugandan population. While public spending 
on healthcare increased along with government spending, the share of health in the budget did not. In fact, it declined slightly between 1989 and 1994. In 1998, Uganda was also the first country to receive debt relief under the HIPC initiative, some $\$ 650$ million reduction in Uganda's multilateral debt stock, although the reduction was delayed by a year which amounted to $\$ 193$ million in lost relief benefits. With the delay, public funds were diverted from spending on health care provision toward debt repayments. A key difference between the Nigerian and Ugandan cases was the relatively higher commitment and spearheading of reform policies in Uganda. The strong commitment from Uganda could have been due to the country's external financing/HIPC status as well.

Between 2000 and 2019, Uganda, a non-commodity dependent country, experienced stable growth rates of around 6.3 percent per year on average. Reforms in the agricultural sector have been credited with halving between 1992 and 2013 the share of households in poverty. Even so, the country still faces challenges in translating recorded growth rates into improvements in human capital like reductions in child stunting and increases in educational attainment for most of its population.

\subsection{Senegal's Experience}

Senegal is another country where reforms have been judged to be largely unsuccessful (Kingston, 2011). Of the three key reforms described in Section 3, Senegal scored highly on two: domestic market-oriented reforms around privatization and fiscal reforms.

The country has a mostly agricultural economy and first received IMF loans in 1984. It completed further transactions with the IMF between 1984 and 2002 under structural adjustment programs. As part of the SAP, Senegal implemented policies to stabilize the financial sector stabilization and cut public spending by 40 percent. Subsidies for staple foods like cooking oil, rice and sugar were reduced or eliminated, resulting in sharp increases 
in domestic prices. Privatization of state-owned enterprises followed in the 1980s. Increased unemployment among public sector workers was one consequence of these reforms. The country reduced debt from 86.2 percent of GDP in 1994 to 71.3 percent in 2000, though some critics pushed back against the benefit of lower debt amidst rising unemployment and declining human capital (Kingston, 2011). Senegal also experienced significant declines in its agricultural sector's contribution to GDP from an average of 18.8 percent in the 1980s to 8.5 percent in 1999. Food production per capita experienced significant declines along with a reduction of the share of primary commodities and food produced domestically.

Since the 2000s, the country has experienced notable increases in economic growth, with GDP growth averaging 4.6 percent between 2000 and 2019. Senegal is not a commodity dependent country, and the services sector was the largest contributor to GDP growth in recent years. The country's stable political climate and attractive macroeconomic environment have been cited as drivers of significant increases in investment over the last few decades.

\section{Discussion and Concluding Remarks}

The speed with which many of the reforms were carried out initially, especially domestic reforms like privatization of SOEs, without careful consideration of the environment of incomplete markets and the institutional challenges faced by African governments, affected the

initial effectiveness of policy implementation and contributed to lower growth rates during the 1980 to 1999 reform period. Over time, countries and their partners learned from past experiences and improved design and implementation of reforms. While total investment as a share of GDP fell through the 1980s period, investment shares stabilized as governments invested in public infrastructure and shoring up security within countries following the democratization wave in the 1990s. By the late 1990s, inflation was significantly reduced. 
The improved macroeconomic environment, in addition to the commodity super cycle of the 2000s and debt reductions, helped to attract more private investment in key sectors like retail, wholesale, telecommunications and manufacturing that accounted for a significant share of the growth increases in the 2000 to 2019 period.

Although the patterns explored here are informative, the empirical evidence presented in this paper do not establish causal effects of Washington Consensus policy adoption on economic performance in African countries. Per capita economic growth was low for reformers over much of the reform period from 1980-1999. The low economic performance may have been a motivator for the reforms, or the lower economic performance may have resulted from the short-term negative effect of the reforms. Both factors were likely at play.

The Washington Consensus framework contained some caveats that were subsequently lost in policy design, creating wedges between the theory of policy reform and the realities of implementation. It cautioned against capital account liberalization and, importantly, warned that privatization should occur with strict regulation only in competitive markets. They also advocated for pro-poor fiscal expenditures and advised against abolishing deregulation designed for safety or environmental reasons. In practice, African governments seeking immediate debt relief were often under significant pressure to quickly meet IFI policy measures under debt conditionality. The weakening of state apparatuses essential in implementing effective reform further reduced the ability of African governments to effectively regulate the pace of policy adoption, with sometimes detrimental consequences for their populations in the initial reform period.

As illustrated through the country case studies, reform experience and outcome differed across countries depending on the particular policy and macroeconomic environments, along with the specific policy objectives of governments in different countries. Policy adoption itself was a political affair, a fact that has largely been ignored in previous analyses of Washington 
consensus policy reforms (Mkandawire and Olukoshi, 1995; Mkandawire and Soludo, 1999; Mkandawire, 1999; Herbst, 1990). While international financial institutions often attributed the lack of success with the reform agenda to weak state capacity, the focus on market orientation and limiting state intervention in development activities led to market failures. State intervention was actually important to implement successful market-oriented reforms in some cases (Mkandawire, 1999).

The criticism of pre-reform policies in Africa is contradicted by the success of development policies in the period immediately post-independence in the 1960s and 1970s (Mkandawire, 1999). Some of the policies that were abandoned in favor of market-oriented reforms had rational, development-motivated justifications. For example, states promoting low interest rates sought to boost investment and capital accumulation. Weaker financial systems with limited competition hindered the achievement of this objective. Subsidies to the agricultural sector, although theoretically inefficient, kept prices low to facilitate access to food for many who lived in poverty, and to reduce the risk of social unrest. Protests against food prices erupted following the removal of subsidies in the 1980s and 1990s. The reforms were often viewed as an infringement on the national sovereignty of countries, which spurred deep resentment among many governments and populations. The irony of effective market oriented reforms is that their implementation requires stable and committed government with a high level of social and political capital. The overwhelming focus of the reforms on macroeconomic stability without the adequate provision of the social safety nets contributed to weaken governments and undermine the reform agenda.

The skeptics of these market oriented reforms in the African context point to the example of countries in Asia where governments played a dominant role for much of the critical phase of their economic development. Even though many Asian countries and African countries were at similar levels of economic development in the 1960s, the former generally enjoy 
a much higher level of development today. Similarly, many of today's developed economies did not embrace widespread free market economies in the earlier phases of their economic development. Their development experience was characterized by state involvement in and control of many sectors. They embraced industrial policies and infant industry protection, heavily subsidized sectors of economies etc ${ }^{3}$. Many of these same practices were frowned upon in Africa by proponents of market-oriented policies.

Even though there is no panacea when it comes to economic reforms, the following lessons provide a useful general guide going forward: First, while market-oriented reforms can be beneficial for growth, each reform policy needs to be carefully considered in the institutional contexts, initial conditions of development and socio-political environment, among others. Second, ownership of the reform agenda by local government with stakeholder buyin is important to encourage support for the reforms and increase the likelihood of success. Third, the negative spillovers of reform policies need to be minimized. Investment in social safety nets is a crucial part of reforms to protect the most vulnerable populations within the countries. Fourth, where reforms aim to achieve macroeconomic stability, they should not trade away social investment in human capital like education and health. Finally, reforms should be a process of continuous re-evaluation, adjustment, and recalibration over the reform period. There is not and will never be a one-size-fits all approach when it comes to economic development, and the reform agenda should be approached carefully and with flexibility.

\footnotetext{
${ }^{3}$ See for example Chang (2002), for a historical perspective on the development experience of today's advanced economies.
} 


\section{Median real GDP per capita growth, SSA}

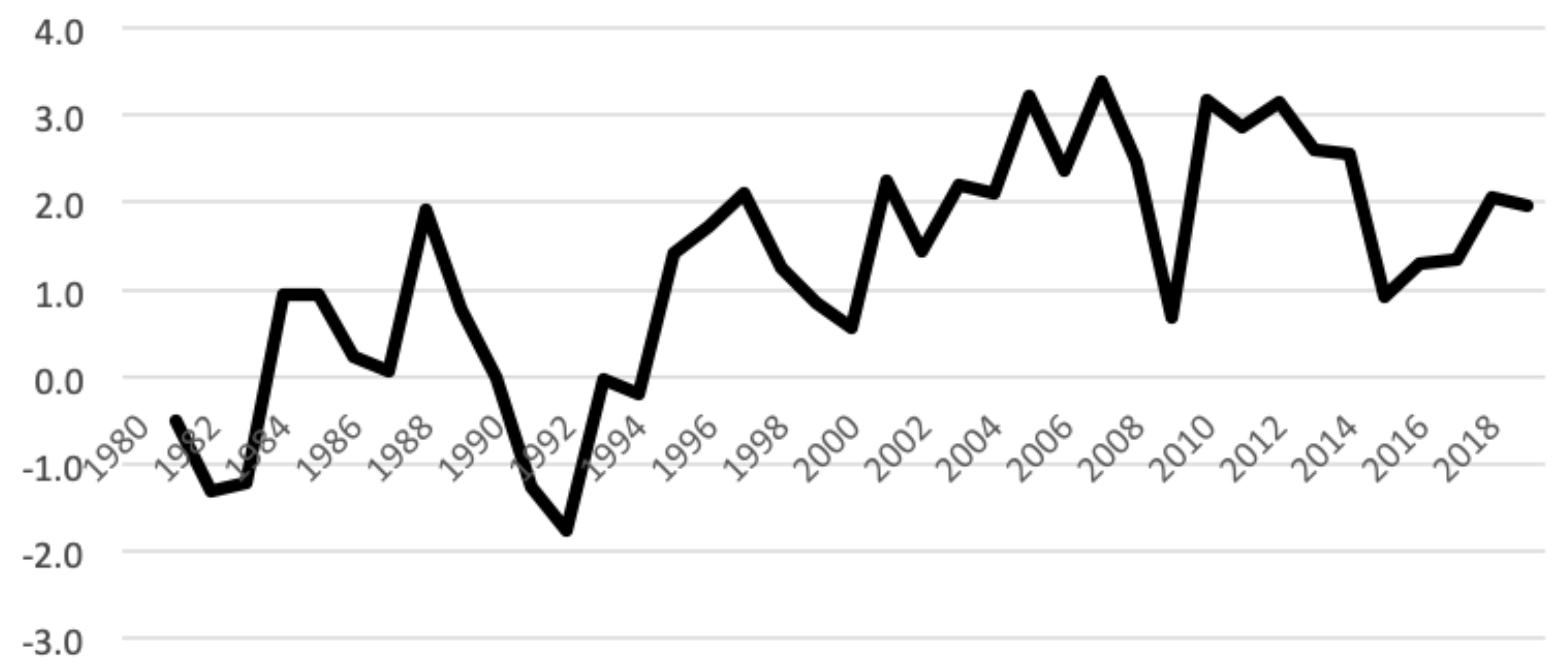

Figure 1: Median real GDP per capita growth rates in SSA, 1980-2019

\section{Median consumer price index, Inflation, SSA}

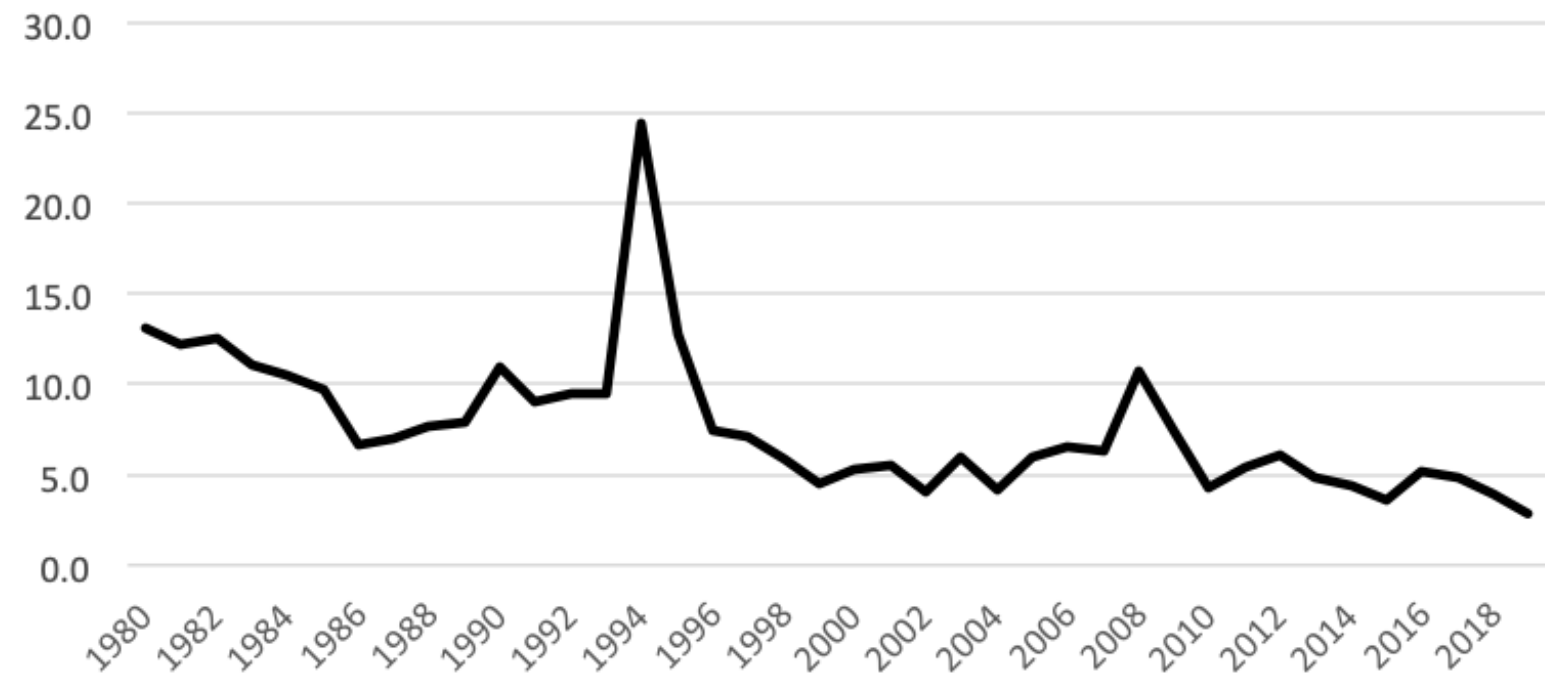

Figure 2: Median consumer price index, inflation in SSA, 1980-2019 


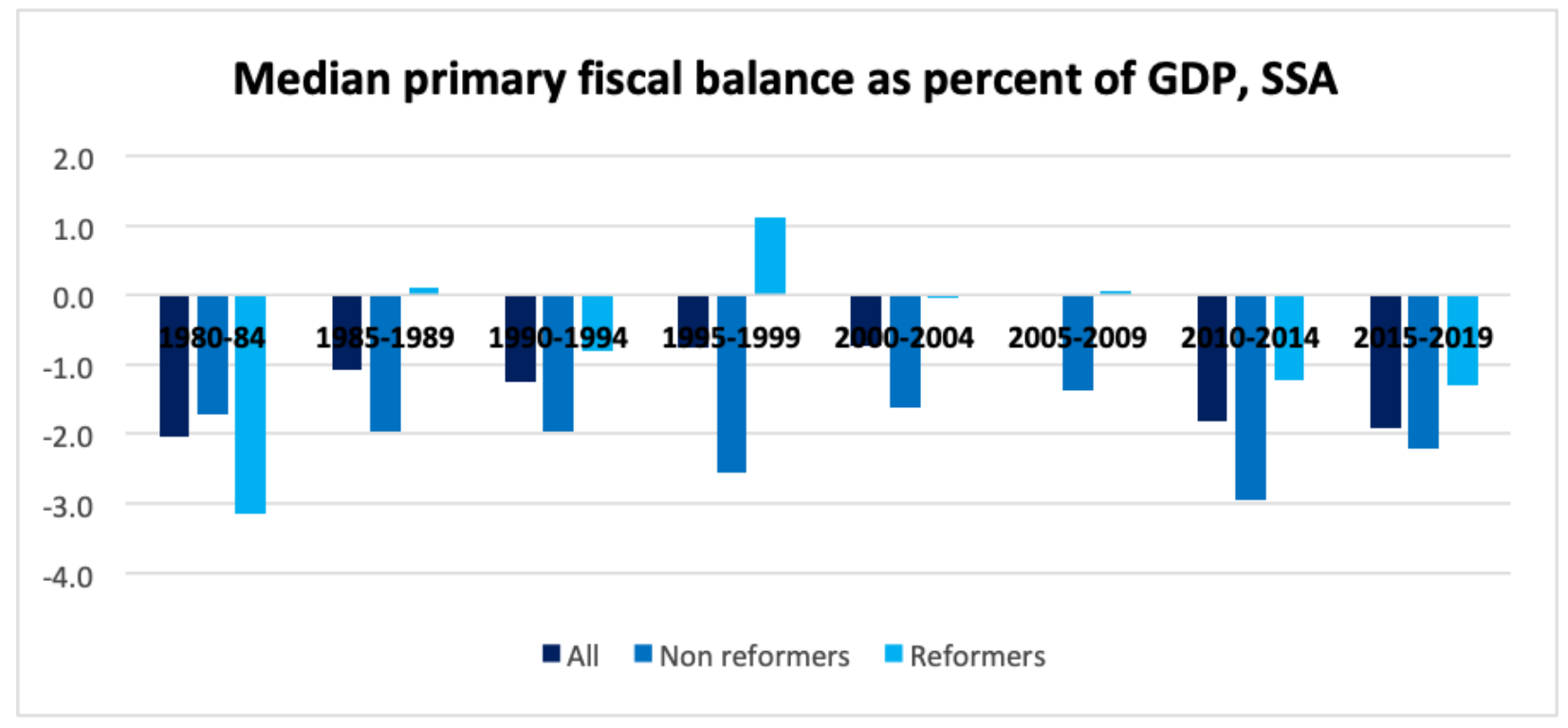

Figure 3: Median primary fiscal balance as a percentage of GDP in SSA, 1980-2019

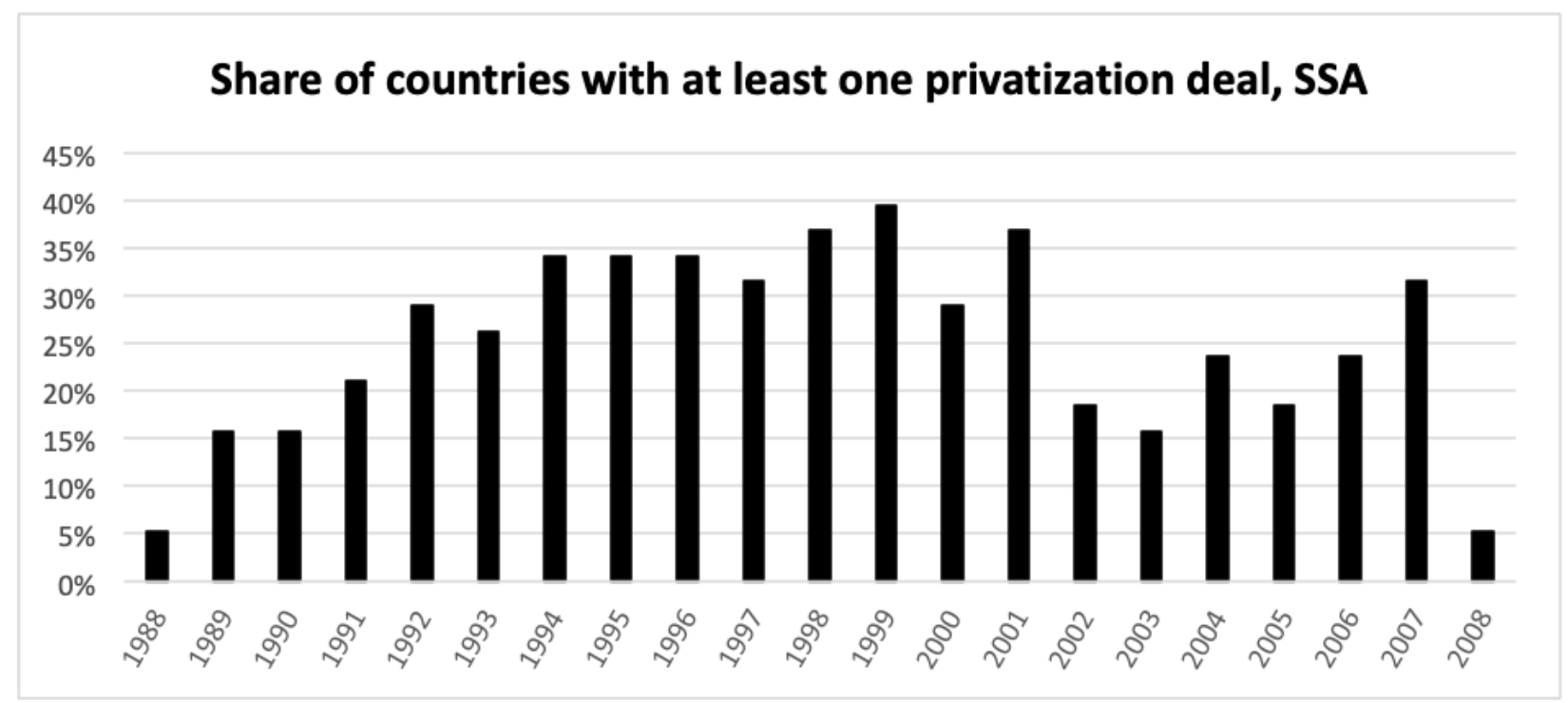

Figure 4: Share of countries with at least one privatization deal in SSA, 1988-2008 
Total number of privitization deals, SSA

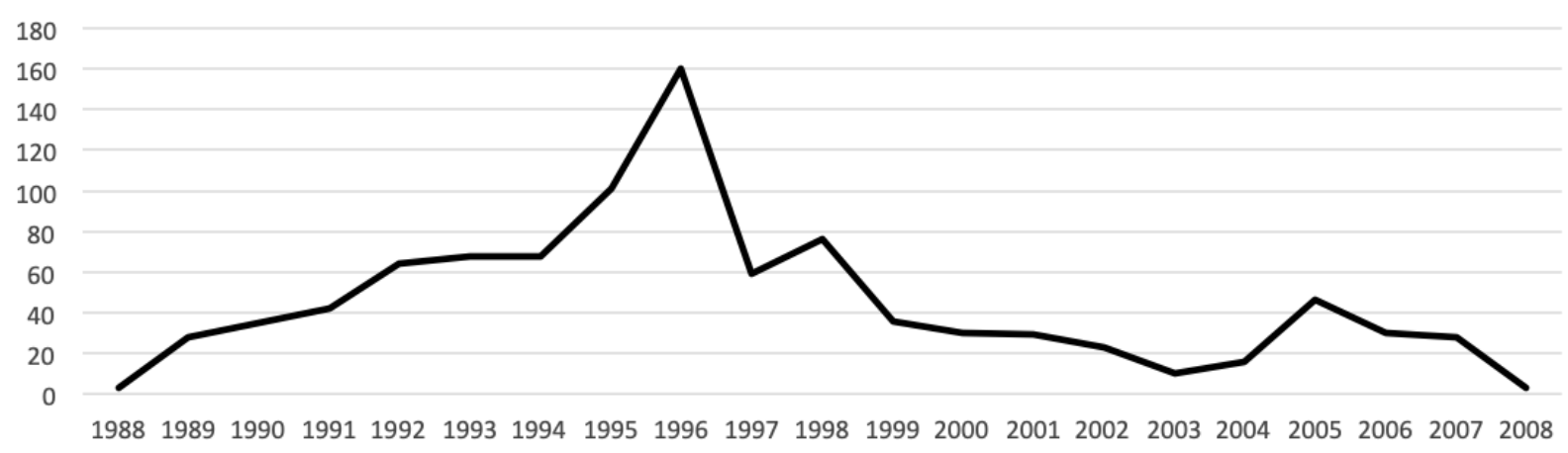

Figure 5: Total number of privatization deals in SSA, 1988-2008

\section{Share of countries open to international trade, SSA}

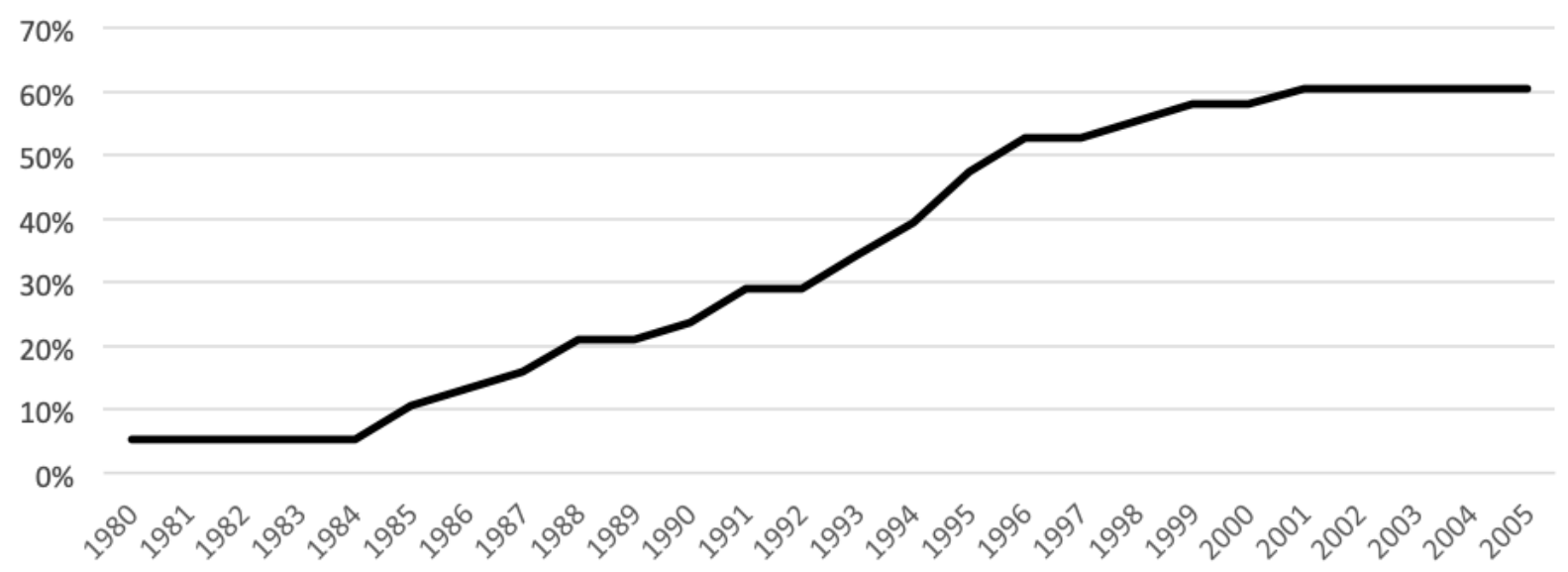

Figure 6: Share of countries open to international trade in SSA, 1980-2005 


\section{Total investment as percent of GDP, SSA}

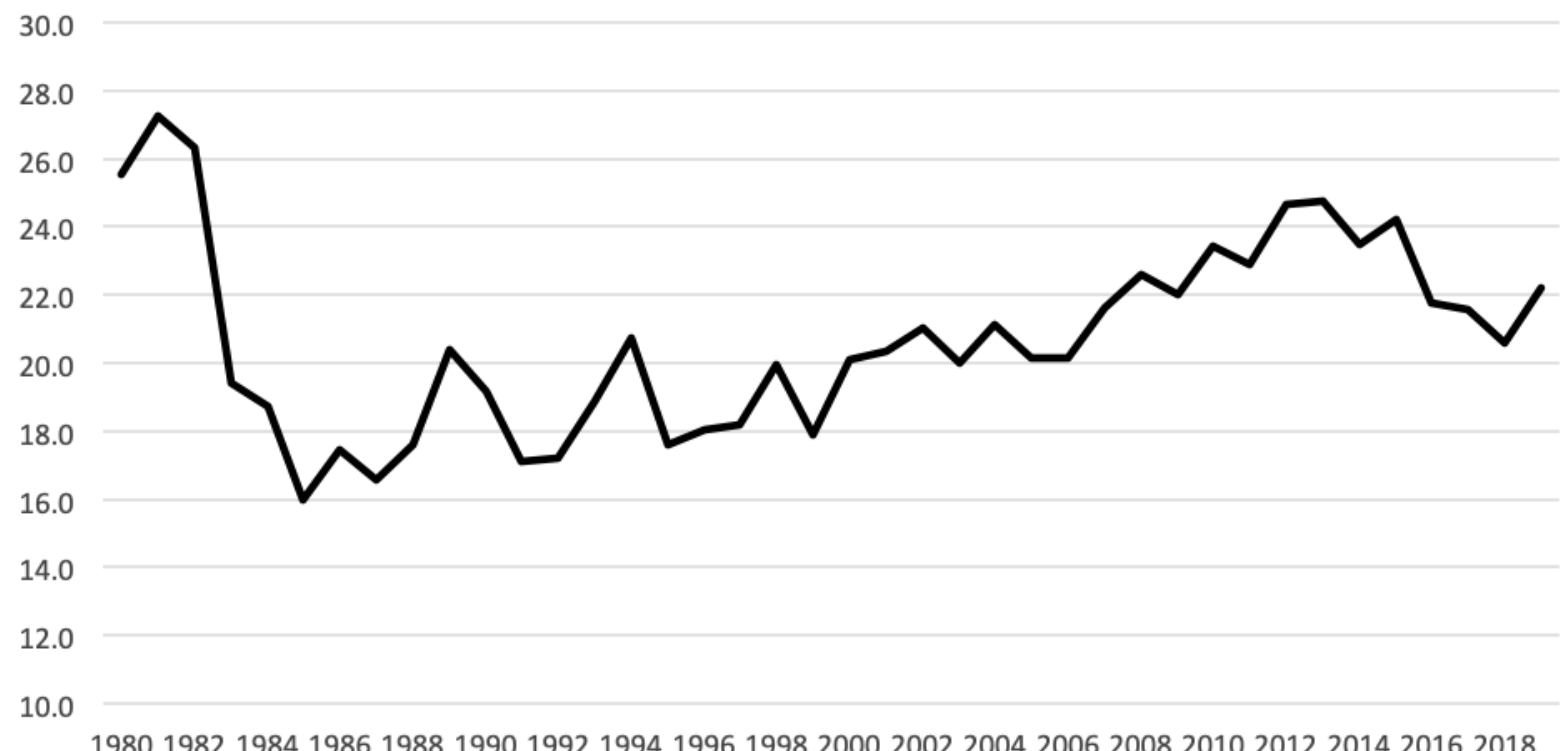

Figure 7: Total investment as a percentage of GDP in SSA, 1980-2019
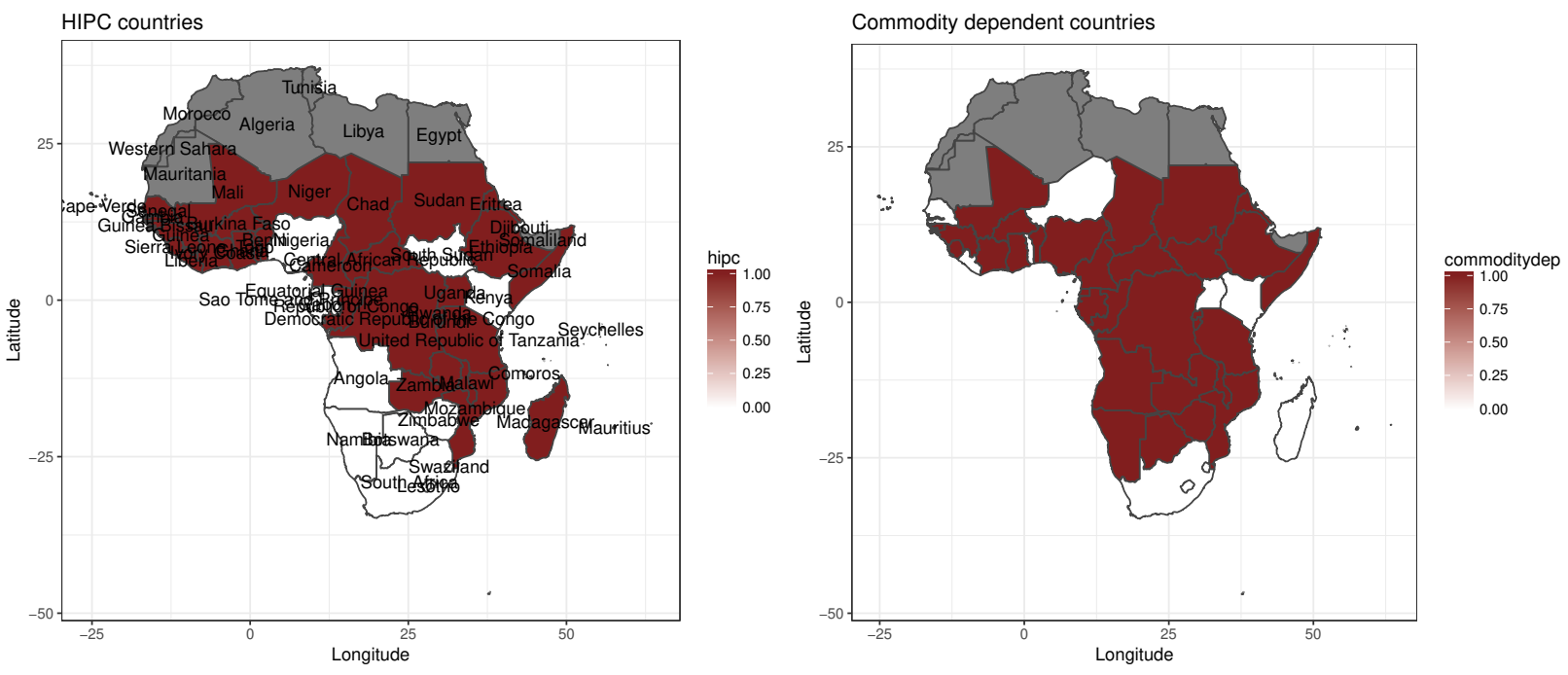

Figure 8: African countries by HIPC and Commodity dependent status 
Table 1: Reform countries in Sub-Saharan Africa (SSA)

\begin{tabular}{ccc}
\hline \hline Domestic Market-Oriented Reforms & Trade Openness & Fiscal Reforms \\
\hline Burundi & Benin & Angola \\
Benin & Botswana & Benin \\
Cote d'Ivoire & Cote d'Ivoire & Central African Republic \\
Ghana & Cameroon & Cote d'Ivoire \\
Kenya & Cabo Verde & Congo, Dem. Rep. \\
Mozambique & Ghana & Congo, Rep. \\
Malawi & Guinea & Gabon \\
Nigeria & Gambia, The & Guinea \\
Senegal & Guinea-Bissau & Guinea-Bissau \\
Togo & Kenya & Kenya \\
Tanzania & Mali & Madagascar \\
Uganda & Mozambique & Mozambique \\
South Africa & Mauritius & Nigeria \\
Zambia & Niger & Rwanda \\
Zimbabwe & Tanzania & Senegal \\
& Uganda & Eswatini \\
& South Africa & Seychelles \\
& & Tanzania \\
& & Uganda \\
\hline
\end{tabular}

Table 2: Reforms and average per capita real GDP growth (\%)

\begin{tabular}{ccccc}
\hline \hline Reforms & Type & $1980-1999$ & $2000-2019$ & Difference \\
\hline \multirow{2}{*}{ Fiscal reforms } & All countries & 0.2 & 1.6 & +1.4 \\
\hline & Reformers & -0.3 & 1.5 & +1.8 \\
& Non-reformers & 1 & 1.8 & +0.8 \\
\hline \multirow{2}{*}{ Domestic market-oriented reforms } & Reformers & -0.6 & 1.5 & +2.1 \\
& Non-reformers & 0.2 & 1.6 & +1.4 \\
\hline \multirow{2}{*}{ Trade-openness } & Reformers & 0.8 & 1.9 & +1.1 \\
& Non-reformers & -0.2 & 1.1 & +1.3 \\
\hline
\end{tabular}


Table 3: Reforms and average per capita real GDP growth (\%) by debt relief recipient status

\begin{tabular}{ccccc}
\hline \hline Type & Reforms & $1980-1999$ & $2000-2019$ & Difference \\
\hline All countries & & 0.2 & 1.6 & +1.4 \\
\hline Non debt relief & & 1.7 & 2 & +0.3 \\
\hline Debt relief & All beneficiaries of debt relief & -0.3 & 2 & +2.3 \\
& Fiscal reformer & -0.4 & 2.2 & +2.6 \\
& Fiscal non-reformer & 0.4 & 1.6 & +1.2 \\
& Market reformer & -0.1 & 2.5 & +2.5 \\
& Market non-reformer & -0.3 & 1.8 & +2.1 \\
& Openness reformer & -0.2 & 2.2 & +2.3 \\
& Openness non-reformer & -0.7 & 1.8 & +2.6 \\
\hline
\end{tabular}

Table 4: Reforms and average per capita real GDP growth (\%) by commodity dependent status

\begin{tabular}{ccccc}
\hline \hline Type & Reforms & $1980-1999$ & $2000-2019$ & Difference \\
\hline All countries & & 0.2 & 1.6 & +1.4 \\
\hline Non commodity dependent & & 0.4 & 2.2 & +1.9 \\
\hline Commodity dependent & All dependent countries & 0.4 & 1.8 & +1.4 \\
& Fiscal reformer & -0.1 & 1.5 & +1.6 \\
& Fiscal non-reformer & 0 & 1.6 & +1.7 \\
& Market reformer & 0 & 2.5 & +2.5 \\
& Market non-reformer & 0.1 & 1.5 & +1.4 \\
& Openness reformer & 0.5 & 1.9 & +1.4 \\
& Openness non-reformer & 0.2 & 1.3 & +1.1 \\
\hline
\end{tabular}




\section{References}

Adedeji, Adebayo. 1999. "Structural adjustment policies in Africa." International Social Science Journal 51 (162): 521-528.

Archibong, Belinda. 2018. "Historical origins of persistent inequality in Nigeria." Oxford Development Studies 46 (3): 325-347.

Ariyo, Ademola, and Afeikhena Jerome. 1999. "Privatization in Africa: an appraisal." World Development 27 (1): 201-213.

Bayliss, Kate, and Christopher Cramer. 2003. "3 Privatisation and the post-Washington consensus." Development Policy in the Twenty-First Century: Beyond the Post-Washington Consensus p. 52 .

Birdsall, Nancy, Felipe Valencia Caicedo, and Augusto De la Torre. 2010. The Washington consensus: assessing a damaged brand. The World Bank.

Chang, Ha-Joon. 2002. "Breaking the mould: an institutionalist political economy alternative to the neo-liberal theory of the market and the state." Cambridge Journal of Economics $26(5): 539-559$.

Chari, Anusha, Peter Blair Henry, and Hector D Reyes. 2020. "The Baker Hypothesis." National Bureau of Economic Research Working Paper.

Coulibaly, Brahima S. 2017. "In Defense of the 'Africa Rising' Narrative." Africa in Focus. https://www. brookings. edu/blog/africa-in-focus/2017/06/27/in-defense-of-theafrica-rising-narrative/. Accessed August 7: 2019.

Coulibaly, Brahima S, Dhruv Gandhi, and Lemma W Senbet. 2019. "Is sub-Saharan Africa facing another systemic sovereign debt crisis?". 
Devarajan, Shantayan, David R Dollar, and Torgny Holmgren. 2002. Aid and reform in Africa. The World Bank.

Dollar, David, and Jakob Svensson. 2000. "What explains the success or failure of structural adjustment programmes?" The Economic Journal 110 (466): 894-917.

Due, Jean M, and Christina H Gladwin. 1991. "Impacts of structural adjustment programs on African women farmers and female-headed households." American Journal of Agricultural Economics 73 (5): 1431-1439.

Easterly, William. 2000. "The effect of IMF and World Bank programs on poverty." Available at SSRN 256883.

Easterly, William. 2019. In search of reforms for growth: New stylized facts on policy and growth outcomes. Technical report National Bureau of Economic Research.

Ekpo, Akpan H. 1992. "Economic development under structural adjustment: evidence from selected West African countries." Journal of Social Development in Africa 7 (1): 25-43.

Elson, Diane. 1995. "Gender awareness in modeling structural adjustment." World Development 23 (11): 1851-1868.

Fernández, Andrés, Stephanie Schmitt-Grohé, and Martín Uribe. 2020. Does the Commodity Super Cycle Matter? Technical report National Bureau of Economic Research.

Grier, Kevin B, and Robin M Grier. 2020. "The Washington Consensus Works: Causal Effects of Reform, 1970-2015." Journal of Comparative Economics .

Herbst, Jeffrey. 1990. "The structural adjustment of politics in Africa." World Development 18 (7): 949-958. 
Ihonvbere, Julius O. 1993. "Economic crisis, structural adjustment and social crisis in Nigeria." World Development 21 (1): 141-153.

Kingston, Kato Gogo. 2011. "The impacts of the World Bank and IMF structural adjustment programmes on Africa: The case study of Cote D'Ivoire, Senegal, Uganda, and Zimbabwe." Sacha Journal of Policy and Strategic Studies 1 (2): 110-130.

Mkandawire, P Thandika, and Charles Chukwuma Soludo. 1999. Our continent, our future: African perspectives on structural adjustment. Idrc.

Mkandawire, Thandika. 1999. "The political economy of financial reform in Africa." Journal of International Development: The Journal of the Development Studies Association 11 (3): $321-342$.

Mkandawire, Thandika, and Adebayo Olukoshi. 1995. Between liberalisation and oppression: the politics of structural adjustment in Africa. Codesria.

Naiman, Robert, and Neil Watkins. 1999. A survey of the impacts of IMF structural adjustment in Africa: Growth, social spending, and debt relief. Preamble Center.

Okonjo-Iweala, Ngozi. 2014. Reforming the unreformable: Lessons from Nigeria. Mit Press.

Onyekwena, Chukwuka, and Amara Mma Ekeruche. 2019. "Is a debt crisis looming in Africa?" Brookings Institution Policy Brief.

Parker, David, and Colin Kirkpatrick. 2005. "Privatisation in developing countries: A review of the evidence and the policy lessons." Journal of Development Studies 41 (4): 513-541.

Prati, Alessandro, Massimiliano Gaetano Onorato, and Chris Papageorgiou. 2013. "Which reforms work and under what institutional environment? Evidence from a new data set on structural reforms." Review of Economics and Statistics 95 (3): 946-968. 
Rodrik, Dani. 2006. "Goodbye Washington consensus, hello Washington confusion? A review of the World Bank's economic growth in the 1990s: learning from a decade of reform." Journal of Economic literature 44 (4): 973-987.

Sachs, Jeffrey D, and Andrew M Warner. 1995. Economic convergence and economic policies. Technical report National Bureau of Economic Research.

Sender, John. 1999. "Africa's economic performance: limitations of the current consensus." Journal of Economic Perspectives 13 (3): 89-114.

Serra, Narcís, and Joseph E Stiglitz. 2008. The Washington consensus reconsidered: Towards a new global governance. OUP Oxford.

Stiglitz, Joseph E. 2005. "More instruments and broader goals: moving toward the postWashington consensus." In Wider perspectives on global development. Springer pp. 16-48.

Williamson, John. 1993. "Democracy and the "Washington consensus"." World development 21 (8): 1329-1336. 